\title{
IMPACT OF THE ENVIRONMENTAL CONDITIONS AND PHYSIOGRAPHIC POSITION ON DEGRADATION OF SOIL AND WATER RESOURCES AT NORTH FAYOUM DEPRESSION, EGYPT
}

\author{
Moustafa M. A. Abou Zied \\ Soil Sci. Dept., Fac. of Agric., Cairo Univ., Egypt
}

ABSTRACT:

This study aims to throw light on the environmental impact as related to soil degradation at north Fayoum depression, with special interest to the heavy metals pollution of some water supplied by a number of drainage canals. This trail was achieved through studying seven sites were carefully selected adjacent to the southern shoreline of Lake Qarun. By nature, these sites are fragile because of constraints imposed by the unique hydrological setting as well as parent material of calcareous in nature, gypsiferous and /or saline and climatic conditions. The obtained results showed wide variations in soil characteristics of these sites, i.e., topographic-sequence (-43 to $-28 \mathrm{~m}$ ), ground-water table depth $(65$ to $>135 \mathrm{~cm}$ ), soil texture grades (loamy sand to clay), $\mathrm{CaCO}_{3}$ content (8.1 to $\left.53.3 \%\right)$, gypsum content (2.83-15.65\%), organic matter $(0.79-3.74 \%)$, soil salinity $(\mathrm{EC}=3.8-87.9 \mathrm{dS} / \mathrm{m})$ and sodicity levels $(\mathrm{ESP}=7.5-47.3)$, consequently they differ in their soil taxonomic units and the suitability classes for agricultural purposes. However, wetness, soil texture, $\mathrm{CaCO}_{3}$, gypsum and salinity/alkalinity are the most effective limitations for soil productivity, with an intensity degree ranged between slight and very severe (rating >90 and <40). Also, the suitability classes of the studied soils could be ranged between unsuitable (N1ws1s3n) and moderately suitable (S2ws1s3n) for the current condition as well as moderately suitable (S2s1) and highly suitable (S1s3).

As a general view, soil macro-morphology showed an extremely salinity for some of the studied soils, which is one additional stressor affects the soil characteristics and the nature and distribution of vegetation. In addition, pounded Aquisalids either developed on the soil surface as brittle salt crusts or fluffy almost snow like crust. The oxidation-reduction chemical reactions (redoximorphic) in subsoil layers can cause changes in the soil $\mathrm{pH}$. The micro-morphological features show that the redox concentrations (mottling) are yellowish brown (Jarosite) in the upper stratum, pale yellow (Limonite) in the mid-profile, reddish brown (Hematite) for the upper fringe of water table and yellowish (Goethite) in the deepest portion. The oxidized zone is characterized by dark grayish brown and slight hard due to the dominance of ferric oxides, while the reduced one shows a dark gray and hard, due to the dominance of ferrous oxides. Also, the $\mathrm{SO}_{4}{ }^{2-}$ enriched deposits encouraging the microbial transformed $\mathrm{H}_{2} \mathrm{~S}$ under the reduction conditions, this medium represents a better environment for transforming amorphous ferric oxides $\left(\mathrm{Fe}_{2} \mathrm{O}_{3}\right)$ to be appeared black in the form of pyrite $\left(\mathrm{FeS}_{2}\right)$. The prevailing environmental conditions are mostly affected the features of $\mathrm{CaCO}_{3}$ and gypsum, which are found in either biorelicts of shell fragments or orthic lime nodules and intercalary clusters of gypsum crystals.

Soil chemical degradation emphasized by salinity and sodicity levels of the studied soil sites, which are coupled with salinity and sodicity levels of both groundwater table and the neighbouring drains. However, the drainage water will be accumulated and resulting in high more saline groundwater table (within $1.5 \mathrm{~m}$ of soil surface), and subsequently waterlogging, high

Fayoum J. Agric. Res. \& Dev., Vol. 21, No.1, January, 2007 
salinization and alkalinization conditions as well as the gleization process, which leads to aquic phase. These conditions led to internal physical, biological and chemical deteriorations as well as led to a reduction in a soil's ability to inactive toxic compounds.

Heavy metal concentrations of either major nutritive (Fe, Mn, $\mathrm{Zn}$ and $\mathrm{Cu})$ or non-nutritive $(\mathrm{Pb}, \mathrm{Cd}, \mathrm{Ni}$ and $\mathrm{Co})$ showed a regular distribution pattern in the groundwater table, drainage water in drains and Lake Qarun. Also, their concentrations at the eastern and middle parts of the studied area, generally, contained higher values, and tended to decrease westwards. This may be attributed to the environmental impact of pollution sources which coming from El Batts and El Wadi drains and many anthropogenic activities. Whereas, heavy metals concentrations in soil were mostly related to soil texture, where the clayey soils exhibited higher available contents of all studied heavy metals as compared to both medium and relatively coarse textured ones. This may be due to the former soils had a larger capacity, high CEC, to adsorb these metals from soil solution

Key words: Soil degradation, heavy metals, El Fayoum depression and environmental pollution.

\section{INTRODUCTION:}

Soil degradation and pollution with heavy metals are of the most serious problems in the northern part of El Fayoum Governorate. Both major problems caused by poor drainage, which is serious in the lower lying areas, and inadequate soil leaching due to shortage of water needed. At the same time, every amount of water, salts and pollutants flows into or is produced within the depression, if not lost due to seepage or evaporation, will be accumulated and resulting in high groundwater table and subsequently waterlogging, high levels of salinization and alkalization. Such soil chemical degradation leads to a reduction in a soil's ability inactive toxic compounds, depletion of major plant nutrients, accumulation of salts and heavy metals (Abdel Razek, 1998).

Lake Qarun is one of the most important physical features of the northern part of the Fayoum depression. It is an enclosed lake and located in the lowest part of El Fayoum depression, and it has an area of about 53000 acres and a depth range between 0.5 and $10.0 \mathrm{~m}$. It is now a brackish water lake with a maximum chlorosity, however, most of the fresh water fish, which used to inhabit the lake, have disappeared. The volume of water flowing daily into the lake and carrying an amount of fine particles is estimated to be about 100000 $\mathrm{m}^{3}$. This volume of water represents the excess of irrigation one $(18 \%$ of the total water supplied to the Fayoum Governorate), which is passed into the lake as drainage water through two main drains, namely El Batts in the eastern part and El Wadi in the western one, in addition to some other minor drains connected to the lake shores.

During the last few years, there is a pronounced change in the water level of Lake Qarun, it is mainly attributed to the variation in both rates of drainage water supply and evaporation. The average water level fluctuates ranged between -43 and $-45 \mathrm{~m}$ (Meshal, 1973). Thus, any more drainage water would damage the neighbouring agricultural soils (Bishai and Kirollus, 1980). Therefore, Lake Qarun as related to adjacent soil sediments attract attention of many authors because of its historical and scientifically importance to study its unique ecosystem. Awadalla (2004) reported that the damage degree for the neighbouring soil areas just adjacent to such inner brackish lake is controlling

Fayoum J. Agric. Res. \& Dev., Vol. 21, No.1, January, 2007 
IMPACT OF THE ENVIRONMENTAL CONDITIONS AND.

by the positive interaction between soil variables as affected by shallow groundwater table (waterlogging aspect) under different locally environments.

Pollution by agro-chemicals is particularly dangerous in the Fayoum depression because its enclosed nature. Studies of pollution within water canals (rivers and drains), lakes and soil sediments have been a major environmental focus, especially in the last decades. Such aspects are important sinks for various pollutants like pesticides, current inadequate sewage disposal; heavyuse of agro-chemicals, potential industrial development or human induced activities and solid waste disposal problems. These pollutants play a significant role in the remobiliza6tion of contaminants in aquatic systems under favourable conditions and in interactions between water and soil sediments (Klavins et al., 2000 and Grosheva et al., 2001). So, knowledge of heavy metal concentrations in lake's or canal's water and adjacent soil sediments is desirable to estimate of pollution criteria as well as for monitoring their widespread and spatial distribution in aquatic ecosystems

The changes in the elemental aspects of both water resources and deteriorated soils and factors affecting under the conditions of north the Fayoum depression were discussed by few Scientific Investigators such as El Naggar (1990) who found that submergence leads to decrease the soil $\mathrm{pH}$ as well as the concentrations of $\mathrm{N}, \mathrm{P}, \mathrm{K}, \mathrm{Zn}$ and $\mathrm{SO}_{4}{ }^{2-}$, especially in the calcareous soil that attained pronounced contents of $\mathrm{CaCO}_{3}$. The reverse was true for $\mathrm{Ca}^{2+}$ and $\mathrm{HCO}_{3}{ }^{-}$, especially with increasing the period of submergence; these obtained data reflect the effects related to soil origins, the intensity of geochemical weathering, physiographic position and prevailing climatic conditions. Also, Farrag (2003) found that the contents of non-nutritive heavy metals showed more pronounced increases towards soils treated with saline drainage water contaminated with sewage effluent at El Fayoum Governorate, where the relative increases reached about 2-4 folds than soils under the favourable conditions. The dominance of such elements follows the descending order of $\mathrm{Fe}>\mathrm{Mn}>\mathrm{Zn}>\mathrm{Cu}>\mathrm{Pb}>\mathrm{B}>\mathrm{Ni}>\mathrm{Co}$ and $\mathrm{Cd}$. According to the safe scale outlined by FAO (1992), these element contents are still within the permissible ranges.

Concentrations of major heavy metals ( $\mathrm{Fe}, \mathrm{Zn}, \mathrm{Mn}, \mathrm{Ni}, \mathrm{Cu}, \mathrm{Co}, \mathrm{Pb}, \mathrm{Cr}$ and $\mathrm{Cd}$ ) were determined in three sites representing east, middle and west of Lake Qarun water and adjacent soil sediments by Mohamed and Fishar (2005). The authors stated that the concentrations of the studied heavy metals show gradually increases westwards away from the effect of El Batts drain. This may be attributed to the impact of pollution sources in the drainage water coming from aforementioned drain. They added that these metals tend to accumulate in various tissues of the different biomass organs and cause serious problems in human, animal and plants. They came to a conclusion that it is must to protect Lake Qarun from anthropogenic sources of pollution to reduce environmental risks.

The present work has been undertaken to evaluate the environmental impact and physiographic position of north Fayoum depression as related to soil degradation and pollution with heavy metals.

\section{MATERIALS AND METHODS:}

To achieve the aforementioned target, seven soil sites were chosen to represent the areas that suffering from seasonally subjected to submerging, flooding and saturating, due to just adjacent to brackish lake of Qarun, taken

Fayoum J. Agric. Res. \& Dev., Vol. 21, No.1, January, 2007 
into consideration that their sediments are covering the most common parent materials, environmental impacts and physiographic positions, which are characterized the northern part of the Fayoum depression, Fig. (1).

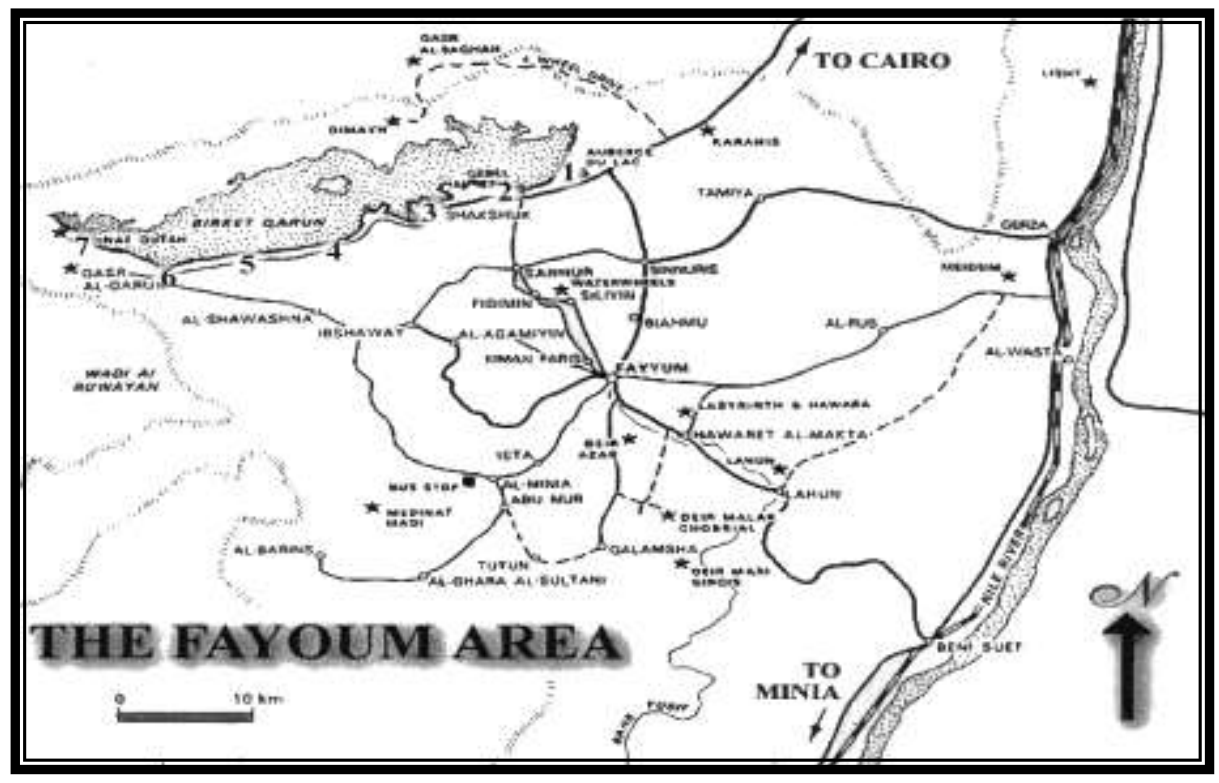

These soils are characterized by low-lying elevation, medium to heavy clay in texture, lack of drainage system and subjected to water seepage from Lake of Qarun or the high-lying elevation alluvial terraces. Table (1) shows a briefly described for the studied area, which represents major freshwater and coastal soils according to Mitsch and Gosselink (1986).

Table (1): A briefly describe for the studied area as major freshwater and coastal soils according to Mitsch and Gosselink. (1986).

\begin{tabular}{|c|c|l|}
\hline Soil types & Forms & \multicolumn{1}{c|}{ Description } \\
\hline $\begin{array}{c}\text { NON-TIDAL } \\
\text { FRESHWATER }\end{array}$ & Lacustrine & $\begin{array}{l}\text { Partial-saturated areas in the form of lacustrine plains } \\
\text { (playas) located adjacent to saline water bodies, less than } \\
30 \text { percent covered by emergent plants. }\end{array}$ \\
\hline
\end{tabular}

At the same time, samples of water were taken from the groundwater table and the neighbouring drainage canals to evaluate their salinity and sodicity levels as well as their contents of heavy metal. The chosen soil profiles were dug to a depth of water table, soil samples were collected from all the studied soil profiles at different depths according the morphological features (FAO, 1990), air dried, crushed to pass a $2 \mathrm{~mm}$ sieve and analyzed for the main soil physical and chemical properties as well as soil contents of some heavy metals ( $\mathrm{Fe}, \mathrm{Mn}, \mathrm{Zn}, \mathrm{Cu}, \mathrm{Pb}, \mathrm{Cd}, \mathrm{Ni}$ and $\mathrm{Co}$ ), as follows:

* Particle size distribution was carried out according to the International Pipette method (Piper, 1950) using sodium hexametaphosphate as a dispersing agent (Richards, 1954).

* Calcium carbonate content was measured using the Collin's Calcimeter method (Wright, 1939).

Fayoum J. Agric. Res. \& Dev., Vol. 21, No.1, January, 2007 
* Gypsum content was determined by precipitation method with acetone (Richards, 1954).

* Organic matter content was determined using the modified Walkely and Black method as described by Jackson (1973).

* Saturation soil paste extract was analyzed for determining ECe, as well as, soil $\mathrm{pH}$ was measured in the soil suspension 1:2.5 (Richards, 1954).

* Cation exchange capacity (CEC) and the exchangeable sodium \% (ESP) were determined using sodium acetate of $\mathrm{pH} 8.2$ and ammonium acetate of $\mathrm{pH} 7$, respectively (Richards, 1954).

* Heavy metals ( $\mathrm{Fe}, \mathrm{Mn}, \mathrm{Zn}, \mathrm{Cu}, \mathrm{Pb}, \mathrm{Cd}, \mathrm{Ni}$ and $\mathrm{Co}$ ) in soil were extracted using ammonium bicarbonate DTPA extract according to Lindsay and Norvell (1978). Their contents in soil extracts were measured by using the Atomic Absorption Spectrophotometer.

* Undisturbed soil samples were taken in Kubiena boxes from the distinguished layers or horizons of the different soil profiles. Thin sections were prepared on the basis of the procedure outlined by Abd El Hamid (1973). Systematic description for the soil sections was recorded according to the systems of Brewer (1964) and Stoops and Jongerius (1975).

The different analysis of water samples of groundwater table and the drainage canals according to the standard methods outlined by Black et al. (1965) and Page et al. (1982). The studied heavy metals (Fe, $\mathrm{Mn}, \mathrm{Zn}, \mathrm{Cu}, \mathrm{Pb}$, $\mathrm{Cd}, \mathrm{Ni}$ and $\mathrm{Co}$ ) in water samples of the groundwater table and the drainage canals were measured using the Atomic Absorption Spectrophotometer.

\section{RESULTS AND DISCUSSION:}

Regional distribution imbalanced is one of the serious problems in the northern part of El Fayoum area, due to an enclosed nature of the depression, more drainage water flowing down the Lake Qarun vs less fresh one is flowing on the lower part of the depression. The studied soil sites are represented by scattered small areas spread on some localities just adjacent to inner brackish Lake Qarun, and they are mainly developed on different parent materials on geomorphic units under different elevation levels, as shown in Table (2).

Table (2): Location, groundwater table, elevation, parent material and geomorphic unit of the studied soil profiles.

\begin{tabular}{|c|c|c|c|c|c|}
\hline $\begin{array}{c}\text { Profile } \\
\text { No. }\end{array}$ & Location & $\begin{array}{c}\text { Water table } \\
(\mathrm{cm})\end{array}$ & $\begin{array}{c}\text { Elevation } \\
(\mathrm{m})\end{array}$ & Parent material & Geomorphic unit \\
\hline 1 & $\begin{array}{l}2 \mathrm{~km} \text { west-north } \\
\text { Menshat Sannuris }\end{array}$ & 65 & -43 & \multirow{2}{*}{ Fluvio-lacustrine } & \multirow{5}{*}{$\begin{array}{l}\text { Recent lake } \\
\text { terraces }\end{array}$} \\
\hline 2 & $\begin{array}{c}1.5 \mathrm{~km} \text { north Ezbet } \\
\text { Yousef }\end{array}$ & 85 & -42 & & \\
\hline 3 & $\begin{array}{c}0.5 \text { west-north } \\
\text { Shakshouk }\end{array}$ & 100 & -43 & Lacustrine & \\
\hline 4 & $\begin{array}{c}1.5 \text { km north Kahk } \\
\text { El Bahriya }\end{array}$ & 105 & -35 & \multirow{2}{*}{ Fluvio-lacustrine } & \\
\hline 5 & $\begin{array}{c}3 \mathrm{~km} \text { north } \\
\text { El Mesharaq }\end{array}$ & 120 & -33 & & \\
\hline 6 & $\begin{array}{c}2 \mathrm{~km} \text { north Ezbet } \\
\text { Mezar }\end{array}$ & 130 & -28 & \multirow{2}{*}{ Colluvial-lacustrine } & \multirow{2}{*}{ Old lake terraces } \\
\hline 7 & $\begin{array}{c}0.5 \mathrm{~km} \text { north Ezbet } \\
\text { Abbazah }\end{array}$ & 135 & -30 & & \\
\hline
\end{tabular}

Fayoum J. Agric. Res. \& Dev., Vol. 21, No.1, January, 2007 


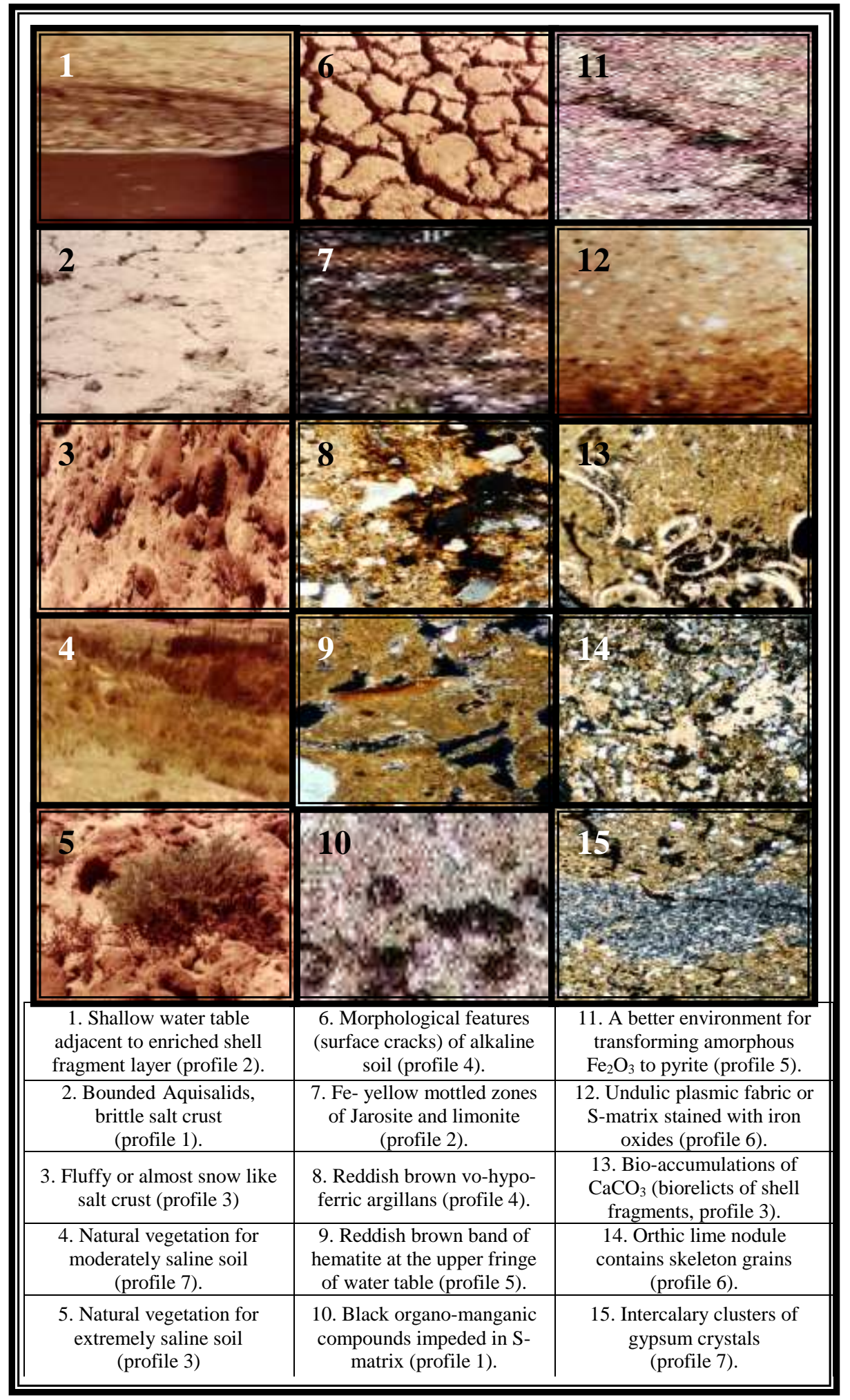

Some macro- and micro-morphological features of the studied soil profiles.

Fayoum J. Agric. Res. \& Dev., Vol. 21, No.1, January, 2007 
IMPACT OF THE ENVIRONMENTAL CONDITIONS AND.

Also, these soil sites, however, in dry climates have formed under high evaporation rates coupled with low effective precipitation, which concentrated salts in the studied soil profiles of these locally wet zones. Therefore, the pedomorphological features, nature of salt concentrations, geo-origin sources and hydric conditions of these soil sites are of important for studying.

\section{Macro, micro-morphological features and some analytical data of the studied soil sites:}

The macro-morphology studies showed that the main characteristics that support the soil sites under investigation are wetness, shallow water table (65-135 $\mathrm{cm}$, Photo 1), anaerobic conditions, different soil texture classes (loamy sand to clayey, Table 3), pounded Aquisalids either develop on the soil surface as brittle salt crusts or fluffy and almost snow like crust (Photos 2 and 3). As a general view, an extremely salinity for some of the studied soils (i. e., profiles 1, 2 and 3), which is one additional stressor affects the soil characteristics as well as the nature and distribution of vegetation (Photos 4 and 5), where its hazardous effect includes increasing the osmotic potential of the soil solution as compared to those of lower salinity levels. These morphological feature were emphasized by the obtained analytical data in Tables (3, 4 and 5), which showed soil salinity levels ranged from non-saline to an extremely salinity $(3.8-87.9 \mathrm{dS} / \mathrm{m})$.

Table (3): Particle size distribution, total $\mathrm{CaCO}_{3}$ and its distribution among soil mechanical fraction of the studied soil profiles.

\begin{tabular}{|c|c|c|c|c|c|c|c|c|c|}
\hline \multirow{2}{*}{$\begin{array}{c}\text { Profile } \\
\text { No. }\end{array}$} & \multirow{2}{*}{$\begin{array}{c}\text { Depth } \\
(\mathrm{cm})\end{array}$} & \multicolumn{3}{|c|}{ Particle size distribution $\%$} & \multirow{2}{*}{$\begin{array}{l}\text { Texture } \\
\text { class* }\end{array}$} & \multirow{2}{*}{$\mathrm{CaCO}_{3}$} & \multicolumn{3}{|c|}{$\mathrm{CaCO}_{3}$ distribution $\%$} \\
\hline & & Sand & Silt & Clay & & & Sand & Silt & Clay \\
\hline \multirow{3}{*}{1} & $0-25$ & 12.7 & 25.4 & 61.8 & Clay & 12.5 & 0.4 & 2.3 & 9.8 \\
\hline & $25-40$ & 8.6 & 27.9 & 63.5 & Clay & 9.3 & 0.5 & 1.2 & 7.6 \\
\hline & $40-65$ & 7.0 & 30.7 & 62.3 & Clay & 8.7 & 0.3 & 1.9 & 6.5 \\
\hline \multirow{3}{*}{2} & $0-15$ & 76.3 & 9.6 & 13.9 & SL & 29.7 & 23.6 & 4.9 & 1.2 \\
\hline & $15-50$ & 69.2 & 12.5 & 18.3 & SCL & 21.4 & 16.8 & 3.1 & 1.5 \\
\hline & $50-85$ & 28.0 & 21.4 & 50.6 & Clay & 11.6 & 1.1 & 1.2 & 9.3 \\
\hline \multirow{3}{*}{3} & $0-20$ & 84.4 & 5.5 & 10.1 & LS & 15.9 & 3.0 & 11.2 & 1.7 \\
\hline & $20-60$ & 62.6 & 9.8 & 27.6 & SCL & 25.2 & 3.6 & 19.3 & 2.3 \\
\hline & $60-100$ & 38.1 & 13.7 & 28.2 & SCL & 12.8 & 2.7 & 3.7 & 6.4 \\
\hline \multirow{3}{*}{4} & $0-35$ & 24.1 & 21.5 & 54.4 & Clay & 10.9 & 0.2 & 1.8 & 8.9 \\
\hline & $35-70$ & 12.6 & 28.3 & 59.1 & Clay & 9.3 & 0.4 & 1.5 & 7.4 \\
\hline & $70-105$ & 5.4 & 32.9 & 61.7 & Clay & 8.1 & 0.5 & 0.9 & 6.7 \\
\hline \multirow{3}{*}{5} & $0-40$ & 62.4 & 11.9 & 25.7 & SCL & 26.8 & 2.5 & 3.9 & 20.4 \\
\hline & $40-80$ & 64.7 & 17.1 & 18.2 & SL & 15.1 & 11.6 & 2.3 & 1.2 \\
\hline & $80-120$ & 21.1 & 35.4 & 43.5 & Clay & 11.8 & 0.7 & 1.5 & 9.6 \\
\hline \multirow{3}{*}{6} & $0-25$ & 29.3 & 38.4 & 32.3 & $\mathrm{CL}$ & 11.8 & 0.9 & 1.2 & 9.7 \\
\hline & $25-80$ & 28.5 & 41.8 & 29.7 & $\mathrm{CL}$ & 20.4 & 1.3 & 1.9 & 17.2 \\
\hline & 80-130 & 13.6 & 62.9 & 23.5 & SiL & 8.2 & 0.5 & 1.4 & 6.3 \\
\hline \multirow{3}{*}{7} & $0-35$ & 84.7 & 4.8 & 10.5 & LS & 18.4 & 12.9 & 4.7 & 0.8 \\
\hline & $35-70$ & 67.3 & 13.5 & 19.2 & SL & 37.9 & 31.4 & 5.1 & 1.4 \\
\hline & $70-135$ & 40.7 & 28.9 & 30.4 & $\mathrm{CL}$ & 53.3 & 39.8 & 7.8 & 5.7 \\
\hline
\end{tabular}

* LS=Loamy sand, $\mathrm{SL}=$ Sandy loam, $\mathrm{SCL}=$ Sandy clay loam, $\mathrm{CL}=$ Clay loam and SiL=Silt loam

Fayoum J. Agric. Res. \& Dev., Vol. 21, No.1, January, 2007 
Moustafa M. A. Abou Zied

Table (4): Chemical analysis of soil paste extract of the studied soil profiles.

\begin{tabular}{|c|c|c|c|c|c|c|c|c|c|c|}
\hline \multirow{2}{*}{$\begin{array}{c}\text { Profile } \\
\text { No. } \\
\end{array}$} & \multirow{2}{*}{$\begin{array}{c}\text { Depth } \\
(\mathrm{cm})\end{array}$} & \multirow{2}{*}{$\begin{array}{c}\mathrm{ECe} \\
(\mathrm{dS} / \mathrm{m})\end{array}$} & \multicolumn{4}{|c|}{ Soluble cations $\left(\mathrm{m} \mathrm{molc} \mathrm{L}^{-1}\right)$} & \multicolumn{4}{|c|}{ Soluble anions $\left(\mathrm{m} \mathrm{molc}^{-1}\right)$} \\
\hline & & & $\mathrm{Ca}^{2+}$ & $\mathrm{Mg}^{2+}$ & $\mathrm{Na}^{+}$ & $\mathrm{K}^{+}$ & $\mathrm{CO}_{3}{ }^{2-}$ & $\mathrm{HCO}_{3}^{-}$ & $\mathrm{Cl}^{-}$ & $\mathrm{SO}_{4}^{2-}$ \\
\hline \multirow{3}{*}{1} & $0-25$ & 56.2 & 33.4 & 140.3 & 391.5 & 2.7 & 0.00 & 2.7 & 430 & 135.2 \\
\hline & $25-40$ & 41.7 & 39.3 & 86.8 & 293.2 & 1.9 & 0.00 & 2.9 & 298 & 120.3 \\
\hline & $40-65$ & 34.5 & 29.8 & 73.9 & 246.0 & 1.3 & 0.00 & 3.1 & 232 & 114.6 \\
\hline \multirow{3}{*}{2} & $0-15$ & 27.5 & 23.8 & 59.1 & 196.7 & 1.1 & 0.00 & 2.5 & 185 & 92.1 \\
\hline & $15-50$ & 22.7 & 19.5 & 56.8 & 153.0 & 0.9 & 0.00 & 2.7 & 167 & 60.5 \\
\hline & $50-85$ & 16.9 & 14.7 & 36.9 & 118.6 & 0.8 & 0.00 & 3.2 & 101 & 69.2 \\
\hline \multirow{3}{*}{3} & $0-20$ & 87.9 & 75.1 & 218.5 & 589.0 & 4.7 & 0.00 & 2.4 & 643 & 241.9 \\
\hline & $20-60$ & 55.2 & 77.2 & 115.9 & 367.0 & 3.0 & 0.00 & 2.6 & 282 & 278.5 \\
\hline & $60-100$ & 43.8 & 39.6 & 109.3 & 294.0 & 2.5 & 0.00 & 2.7 & 319 & 123.7 \\
\hline \multirow{3}{*}{4} & $0-35$ & 7.9 & 7.0 & 16.0 & 56.5 & 1.6 & 0.40 & 4.2 & 48 & 28.1 \\
\hline & $35-70$ & 8.4 & 8.2 & 15.1 & 60.0 & 1.2 & 0.80 & 4.7 & 54 & 25.0 \\
\hline & $70-105$ & 11.7 & 10.5 & 20.7 & 85.8 & 0.9 & 1.30 & 5.1 & 69 & 42.5 \\
\hline \multirow{3}{*}{5} & $0-40$ & 8.9 & 32.4 & 18.7 & 38.7 & 0.9 & 0.00 & 2.4 & 50. & 38.3 \\
\hline & $40-80$ & 11.7 & 43.6 & 21.8 & 53.1 & 0.7 & 0.00 & 2.5 & 62 & 54.7 \\
\hline & $80-120$ & 13.4 & 49.2 & 27.5 & 58.2 & 0.5 & 0.00 & 2.6 & 70 & 62.8 \\
\hline \multirow{3}{*}{6} & $0-25$ & 3.8 & 9.8 & 12.9 & 15.4 & 0.6 & 0.00 & 2.2 & 20 & 16.5 \\
\hline & $25-80$ & 4.2 & 11.0 & 14.4 & 16.6 & 0.5 & 0.00 & 2.5 & 23 & 17.0 \\
\hline & $80-130$ & 6.1 & 16.2 & 20.9 & 24.5 & 0.3 & 0.00 & 2.6 & 27 & 32.3 \\
\hline \multirow{3}{*}{7} & $0-35$ & 4.7 & 13.1 & 15.7 & 17.9 & 1.2 & 0.00 & 2.7 & 30 & 15.2 \\
\hline & $35-70$ & 6.1 & 20.2 & 19.5 & 20.3 & 0.8 & 0.00 & 3.0 & 37 & 21.8 \\
\hline & 70-135 & 9.8 & 45.7 & 21.3 & 32.1 & 0.6 & 0.00 & 3.1 & 38 & 57.6 \\
\hline
\end{tabular}

Table (5): Some chemical characteristics of the studied soil profiles.

\begin{tabular}{|c|c|c|c|c|c|c|}
\hline $\begin{array}{c}\text { Profile } \\
\text { No. }\end{array}$ & $\begin{array}{c}\text { Depth } \\
(\mathrm{cm})\end{array}$ & $\begin{array}{c}\mathrm{pH}(1: 2.5 \\
\text { soil susp. })\end{array}$ & SAR & ESP & $\begin{array}{c}\text { Organic } \\
\text { matter } \%\end{array}$ & $\begin{array}{c}\text { Gypsum } \\
\%\end{array}$ \\
\hline \multirow{4}{*}{1} & $0-25$ & 7.95 & 42.01 & 19.8 & 3.64 & 3.92 \\
\cline { 2 - 7 } & $25-40$ & 7.83 & 36.93 & 24.2 & 2.85 & 4.15 \\
\cline { 2 - 7 } & $40-65$ & 7.69 & 34.17 & 28.5 & 1.72 & 6.87 \\
\hline \multirow{4}{*}{2} & $0-15$ & 7.85 & 30.54 & 10.9 & 2.96 & 5.74 \\
\cline { 2 - 8 } & $15-50$ & 7.93 & 24.76 & 14.6 & 1.65 & 6.96 \\
\cline { 2 - 8 } & $50-85$ & 8.21 & 25.35 & 21.4 & 0.89 & 7.25 \\
\hline \multirow{4}{*}{3} & $0-20$ & 7.81 & 48.60 & 23.9 & 2.08 & 2.83 \\
\cline { 2 - 8 } & $20-60$ & 7.92 & 37.33 & 27.4 & 1.67 & 3.90 \\
\cline { 2 - 8 } & $60-100$ & 7.98 & 34.07 & 31.6 & 0.92 & 5.09 \\
\hline \multirow{4}{*}{4} & $0-35$ & 8.54 & 16.67 & 36.4 & 3.15 & 3.79 \\
\cline { 2 - 8 } & $35-70$ & 8.69 & 17.59 & 41.6 & 2.32 & 5.14 \\
\cline { 2 - 8 } & $70-105$ & 8.73 & 21.72 & 47.3 & 0.97 & 7.69 \\
\hline \multirow{3}{*}{5} & $0-40$ & 7.67 & 7.66 & 9.7 & 2.46 & 4.82 \\
\cline { 2 - 8 } & $40-80$ & 7.71 & 9.28 & 11.2 & 1.89 & 7.05 \\
\cline { 2 - 8 } & $80-120$ & 7.75 & 9.40 & 13.5 & 0.97 & 8.63 \\
\hline \multirow{3}{*}{6} & $0-25$ & 7.83 & 4.57 & 9.7 & 2.43 & 5.32 \\
\cline { 2 - 8 } & $25-80$ & 7.95 & 4.66 & 10.2 & 1.18 & 9.57 \\
\cline { 2 - 8 } & $80-130$ & 8.12 & 5.68 & 8.9 & 0.79 & 13.18 \\
\hline \multirow{3}{*}{7} & $0-35$ & 8.13 & 3.79 & 7.5 & 1.97 & 4.17 \\
\cline { 2 - 8 } & $35-70$ & 8.20 & 4.46 & 9.1 & 1.25 & 7.94 \\
\cline { 2 - 8 } & $70-135$ & 8.32 & 5.79 & 9.7 & 0.81 & 15.65 \\
\hline
\end{tabular}

Fayoum J. Agric. Res. \& Dev., Vol. 21, No.1, January, 2007 
Also, increasing soil $\mathrm{pH}(>8.50)$ and ESP (36.4-47.3\%) values, beside the occurrence of soluble $\mathrm{CO}_{3}^{2-}\left(0.4-1.3 \mathrm{~m} \mathrm{molc}^{-1}\right)$, are mainly attributed to the dominance of soil alkalinity, as shown at soil site 4 and illustrated in Tables (4 and 5), which reflected the morphological features of surface cracks (Photo 6). The studied micro-morphological features of mottling, in subsoil layers due to redox concentrations, show that the colours of Fe-mottled zones (Photos 7 and 8) are yellowish brown (Jarosite) in the upper stratum, pale yellow (Limonite) in the mid-profile, reddish brown (Hematite, Photo 9) for the upper fringe of water table and yellowish (Goethite) in the deepest portion. The iron transformation accompanied the fluctuation of shallow water table indicates that the oxidized zone is characterized by dark grayish brown and slight hard due to the dominance of ferric oxides, while the reduced one shows a dark gray and hard, due to the dominance of ferrous oxides.

Organo-manganic compounds can cause some redox concentrations to appear black (Photo 10). Fe can be also appeared black in the form of pyrite (Photo 11), which reflects the $\mathrm{SO}_{4}{ }^{2-}$ enriched deposits, then microbial transformed to $\mathrm{H}_{2} \mathrm{~S}$ under the reduction conditions. These media represent a better environment for transforming amorphous ferric oxides of $\mathrm{Fe}_{2} \mathrm{O}_{3}$ to $\mathrm{FeS}_{2}$ (pyrite). Also, gleization process is more pronounced at the subsoil layers, which leads to aquic phase. In addition, some pedogenic Fe-features are represented by either an undulic plasmic fabric stained with iron oxides (Photo 12) or orthic concretions of vo-hypoferriargillans (Photo 8). Organic matter accumulation (0.79-3.64 \%) is an important characteristic of the studied soils due to the heavy density of natural vegetation in some localities (Photo 4), and reduced decomposition of organic materials under the extremely saline media in another ones that result in the development of organic-rich surface soil layers. Also, the oxidation-reduction chemical reactions (redoximorphic) can cause metabolic products of microbial reducing reactions under the anaerobic conditions, and in turn it causes changes in the soil $\mathrm{pH}$.

The studied micro-morphological features of both soil $\mathrm{CaCO}_{3}(8.1-53.3$ $\%$ ) and gypsum contents (2.83-15.65 \%) reflect the effects of soil origin, intensive of weathering type and environmental conditions, where they are occurred either as a fine fraction (secondary feature of silt and clay in fluviolacustrine deposits) or as coarse one (primary form of sand in the colluviallacustrine ones) as well as intercalary crystals (gypsum), Tables (3 and 5). These prevailing environmental conditions are mostly affected the features of $\mathrm{CaCO}_{3}$, which are found in the bio-accumulations (biorelicts of shell fragments, Photo 13), secondary stage (orthic lime nodule contains skeleton grains, Photo 14) and gypsum accumulations exhibited as intercalary clusters of gypsum crystals (Photo 15).

\section{Soil taxonomy and evaluation:}

Based on the obtained data of soil morphology and physico-chemical properties, the soils under investigation could be classified up to the family level into seven taxonomic units according to Soil Survey Staff (2003), as shown in Table (6). 
Table (6): Taxonomic units of the studied soils at the family level.

\begin{tabular}{|c|c|c|}
\hline Order & Soil site & Taxonomic unit \\
\hline \multirow{2}{*}{ Vertisols } & 1 & Aquic Salitorrerts, very fine clayey, smectitic, hyperthermic \\
\cline { 2 - 3 } & 2 & Typic Calcigypsids, clayey, smectitic, hyperthermic \\
\hline \multirow{3}{*}{ Aridisols } & $3 \& 6$ & Typic Calcigypsids, fine loamy, mixed, hyperthermic \\
\cline { 2 - 3 } & 4 & Typic Gypsitorrerts, fine clayey, smectitic, hyperthermic \\
\cline { 2 - 3 } & $5 \& 7$ & Typic Calcigypsids, coarse loamy, mixed, hyperthermic \\
\hline
\end{tabular}

The results of soil evaluation in Table (7), which are based on the parametric system undertaken by Sys and Verheye (1978), show that the estimated current ratings of the studied soils. The obtained values range between 6.83 and 51.30, indicate that they could be categorized into two classes, i.e., unsuitable (N1ws1s3n) and moderately suitable (S2ws1s3n). For raise their capability potential, smooth land leveling, lowering groundwater table, removing the excess of soluble salts and ESP should be carried out under an efficient drainage ditches as well as applying the gypsum requirements and organic fertilization. Such agro-management practices will be corrected the ratings of soil potential suitability classes to be ranged 65.00-90.00, and potential soil suitability becomes two classes, i.e., moderately suitable (S2s1) and highly suitable ( $\left.\mathrm{S}_{13} 3\right)$. It is noteworthy to mention that the prevailing salinization and sodicity, beside the anaerobic condition, represent adversely affecting through unsuitable media for nutrients availability and mechanism of nutrients uptake by plant roots

Table (7): Soil limitations and rating indices for the evaluation of the studied soils.

\begin{tabular}{|c|c|c|c|c|c|c|c|c|c|c|c|}
\hline \multirow[b]{2}{*}{ 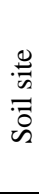 } & \multirow[b]{2}{*}{ 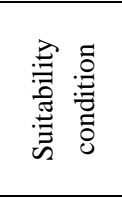 } & \multirow[b]{2}{*}{ 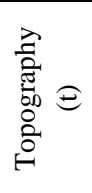 } & \multirow[b]{2}{*}{ 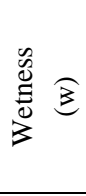 } & \multicolumn{4}{|c|}{$S$} & \multirow[b]{2}{*}{ 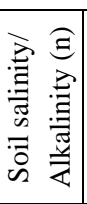 } & \multirow[b]{2}{*}{ 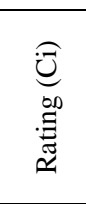 } & \multirow{2}{*}{ 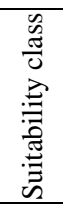 } & \multirow[b]{2}{*}{ 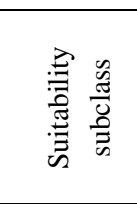 } \\
\hline & & & & 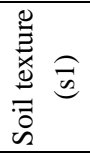 & 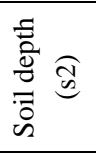 & $\bigcup_{\tilde{U}}^{\infty} \widehat{\tilde{\sigma}}$ & 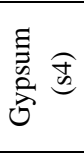 & & & & \\
\hline \multirow{2}{*}{1} & Current & 100 & 35 & 65 & 100 & 100 & 100 & 30 & 6.83 & N1 & N1ws1n \\
\hline & Potential & 100 & 100 & 65 & 100 & 100 & 100 & 100 & 65.00 & $\mathrm{~S} 2$ & S2s1 \\
\hline \multirow{2}{*}{2} & Current & 100 & 50 & 85 & 100 & 90 & 100 & 75 & 28.89 & $\mathrm{~S} 3$ & S3ws1s3n \\
\hline & Potential & 100 & 100 & 85 & 100 & 90 & 100 & 100 & 76.50 & $\mathrm{~S} 1$ & S1s1s3 \\
\hline \multirow{2}{*}{3} & Current & 100 & 70 & 95 & 100 & 90 & 100 & 58 & 34.71 & S3 & S3ws1s3n \\
\hline & Potential & 100 & 100 & 95 & 100 & 90 & 100 & 100 & 85.50 & $\mathrm{~S} 1$ & S1 s1s3 \\
\hline \multirow{2}{*}{4} & Current & 100 & 50 & 85 & 100 & 100 & 100 & 50 & 21.25 & N1 & N1ws1n \\
\hline & Potential & 100 & 100 & 85 & 100 & 100 & 100 & 100 & 85.00 & $\mathrm{~S} 1$ & S1s1 \\
\hline \multirow{2}{*}{5} & Current & 100 & 70 & 95 & 100 & 90 & 100 & 85 & 50.87 & $\mathrm{~S} 2$ & S2w s1s3n \\
\hline & Potential & 100 & 100 & 95 & 100 & 90 & 100 & 100 & 85.50 & $\mathrm{~S} 1$ & S1 s1s3 \\
\hline \multirow{2}{*}{6} & Current & 100 & 95 & 100 & 100 & 90 & 100 & 90 & 76.95 & $\mathrm{~S} 1$ & S1ws3n \\
\hline & Potential & 100 & 100 & 100 & 100 & 90 & 100 & 100 & 90.00 & $\mathrm{~S} 1$ & S1s3 \\
\hline \multirow{2}{*}{7} & Current & 100 & 95 & 75 & 100 & 80 & 100 & 90 & 51.30 & $\mathrm{~S} 2$ & S2w s1s3n \\
\hline & Potential & 100 & 100 & 75 & 100 & 80 & 100 & 100 & 60.00 & $\mathrm{~S} 1$ & S1 s1s3 \\
\hline
\end{tabular}

Fayoum J. Agric. Res. \& Dev., Vol. 21, No.1, January, 2007 
IMPACT OF THE ENVIRONMENTAL CONDITIONS AND.

III. Chemical analysis of water samples collected from both groundwater table and the neighbouring drains:

Data in Tables $(4,5$ and 8) emphasized that salinity and sodicity levels of the studied soil sites are coupled with salinity and sodicity levels of both underlain groundwater table and the neighbouring drains. The drainage water in the studied areas (the lower lying north part of El Fayoum depression) is a function of an incised drains system developed on the Fayoum depression and the deepest of these drains today carry the Wadi and El Batts drains,. where Lake Qarun receives the drainage water from these drains.

Table (8): Chemical analysis of water samples collected from groundwater table and the neighbouring drains.

\begin{tabular}{|c|c|c|c|c|c|c|c|c|c|c|c|c|}
\hline \multirow{2}{*}{$\begin{array}{l}\text { Soil } \\
\text { site }\end{array}$} & \multirow{2}{*}{$\begin{array}{l}\text { Water } \\
\text { sample }\end{array}$} & \multirow{2}{*}{$\mathrm{pH}$} & \multirow{2}{*}{$\begin{array}{c}\mathrm{ECe} \\
(\mathrm{dS} / \mathrm{m})\end{array}$} & \multicolumn{4}{|c|}{ Soluble cations $\left(\mathrm{m}\right.$ molc $\left.\mathrm{L}^{-1}\right)$} & \multicolumn{4}{|c|}{ Soluble anions $\left(\mathrm{m} \mathrm{molc} \mathrm{L}^{-1}\right)$} & \multirow{2}{*}{ SAR } \\
\hline & & & & $\mathrm{Ca}^{2+}$ & $\mathrm{Mg}^{2+}$ & $\mathrm{Na}^{+}$ & $\mathrm{K}^{+}$ & $\mathrm{CO}_{3}^{2-}$ & $\mathrm{HCO}_{3}^{-}$ & $\mathrm{Cl}^{-}$ & $\mathrm{SO}_{4}{ }^{2-}$ & \\
\hline \multirow{2}{*}{1} & G & 7.65 & 41.3 & 36.6 & 10.3.1 & 272.6 & 3.2 & 0.00 & 6.5 & 297 & 112.0 & 27.13 \\
\hline & $\mathrm{D}^{*}$ & 7.52 & 4.3 & 5.7 & 8.2 & 29.1 & 0.8 & 0.00 & 5.2 & 24.4 & 14.2 & 11.02 \\
\hline \multirow{2}{*}{2} & $\mathrm{G}$ & 7.71 & 20.6 & 18.3 & 51.7 & 135.0 & 2.5 & 0.00 & 7.2 & 148.0 & 53.3 & 22.80 \\
\hline & $\mathrm{D}$ & 7.63 & 3.4 & 4.8 & 6.2 & 24.0 & 0.6 & 0.00 & 6.0 & 18.0 & 11.6 & 10.21 \\
\hline \multirow{2}{*}{3} & $\mathrm{G}$ & 7.83 & 59.7 & 54.0 & 153.6 & 393.0 & 4.7 & 0.00 & 6.1 & 369.0 & 230.2 & 38.57 \\
\hline & D & 7.71 & 5.8 & 11.5 & 14.4 & 31.9 & 2.9 & 0.00 & 4.9 & 32.5 & 22.3 & 8.86 \\
\hline \multirow{2}{*}{4} & G & 8.15 & 38.5 & 41.6 & 80.3 & 266.5 & 3.7 & 0.00 & 7.5 & 235.0 & 149.6 & 34.12 \\
\hline & $\mathrm{D}$ & 7.96 & 4.7 & 10.9 & 12.7 & 22.5 & 2.1 & 0.00 & 6.4 & 31.0 & 10.8 & 6.54 \\
\hline \multirow{2}{*}{5} & G & 7.80 & 9.8 & 31.9 & 20.1 & 46.4 & 2.7 & 0.00 & 5.3 & 51.5 & 44.3 & 9.12 \\
\hline & $\mathrm{D}$ & 7.62 & 2.9 & 7.0 & 7.8 & 12.5 & 1.5 & 0.00 & 6.7 & 13.3 & 8.8 & 4.59 \\
\hline \multirow{2}{*}{6} & G & 7.83 & 5.3 & 8.4 & 19.3 & 23.9 & 2.1 & 0.00 & 7.9 & 32.5 & 13.3 & 6.42 \\
\hline & $\mathrm{D}$ & 7.77 & 2.8 & 6.7 & 7.5 & 12.3 & 1.6 & 0.00 & 5.8 & 12.6 & 9.7 & 4.62 \\
\hline \multirow{2}{*}{7} & G & 7.95 & 6.9 & 11.7 & 25.2 & 32.3 & 1.7 & 0.00 & 6.8 & 42.9 & 21.2 & 7.53 \\
\hline & $\mathrm{D}$ & 7.65 & 2.8 & 6.9 & 7.6 & 13.2 & 1.4 & 0.00 & 6.1 & 13.0 & 10.0 & 4.87 \\
\hline \multicolumn{2}{|c|}{ Lake Qarun } & 7.92 & 39.8 & 32.8 & 95.9 & 269.6 & 4.9 & 0.00 & 7.1 & 294 & 102.1 & 33.49 \\
\hline
\end{tabular}

$\mathrm{G}=$ Groundwater table and $\mathrm{D}=$ Drain

*1=Batts Said, 2= Khour El Heitan, 3= El Sheikh Allam, 4=El Hammam, 5= Batn Ahreit, 6=El Mesharaq \& 7=El Eslah

Consequently, Qarun Lake levels are negatively influenced on the adjacent soils, this is mainly associated with increasing lateral seepage of its saline drainage water to the neighbouring soils and acceleration of the rise in groundwater tables. Concerning the specific soluble ions, it is noteworthy to mention that the soluble cations and anions showed a regular distribution pattern in the extremely saline soils and both groundwater table and drainage water. It could be categorized the soluble ions in the studied water samples at a descending order of $\mathrm{Na}^{+}<\mathrm{Mg}^{2+}<$ $\mathrm{Ca}^{2+}<\mathrm{K}^{+}$for soluble cations vs $\mathrm{Cl}^{-}<\mathrm{SO}_{4}{ }^{2-}<\mathrm{HCO}_{3}{ }^{-}<\mathrm{CO}_{3}{ }^{-}$for soluble anions.

\section{Soil degradation:}

Soil degradation status is of the most serious problems in the studied area of north Fayoum depression, due to it is just adjacent to Lake Qarun as well as those with an uncontrolled population growth without a corresponding increase of the efficiency of the soils subsequently. This phenomenon is a specially serious in such lower lying areas, and mostly attributed to poor drainage as well as due to the lateral seepage from the saline water bodies (Lake Qarun). In addition, it is already inadequate soil leaching under shortage of water due to its lying on the tail end areas of the Fayoum depression. So, every amount of water or salts flows into or is produced within this area of the depression, if not lost due to seepage or evaporation, will be accumulated and resulting in high more saline groundwater

Fayoum J. Agric. Res. \& Dev., Vol. 21, No.1, January, 2007 
table (within $1.5 \mathrm{~m}$ of soil surface) and subsequently waterlogging, high salinization and alkalinization levels (Tables 2, 4 and 5). One of the categories of human induced activities, soil degradation is internal soil deterioration, i.e., physical, biological and chemical deteriorations. Also, it is noticed that soil salinity and alkalinity levels are therefore the coupled relation between both the neighbouring drainage canals and Lake Qarun water in these lower lying areas within the closed environment of the Fayoum depression.

Therefore, regional distribution imbalanced is one of the serious problems in the Fayoum depression of an enclosed nature, due to more drainage water flowing down the Lake Qarun vs less fresh one is flowing on the lower part of the depression, since the latter is located at the tail ends. Moreover, soil chemical degradation resulted in deterioration of soil structure due to dispersion of stable aggregates by $\mathrm{Na}$ and $\mathrm{Mg}$ salts, especially in the subsoil layers (sodification) as well as led to a reduction in a soil's ability to inactive toxic compounds. Also, the gleization process is more pronounced at the subsoil layers, which leads to aquic phase, as discussed before. These obtained results are emphasized by the data of salinity map updated in 1995 and outlined by Abd El Motaleb (1997) who found that the saline areas (ECe $>8 \mathrm{dS} / \mathrm{m}$ ) increased by about 34346 feddans than those of found in 1982 (SWRI, 1982). The author mentioned also that these recent saline areas are concentrated mainly around Lake Qarun.

\section{$V$. Pollution of soil and water resources:}

Risks serious water and soil pollution in the studied areas in the Fayoum depression are high because of many factors, i. e., current inadequate sewage treatment of the villages which pass for domestic purposes, heavy use of agrochemical, pesticides, potential industrial development and solid water disposal problems. Such factors caused a pronounced development of toxicities, especially in the paddy fields of the studied soil sites (Table 9).

Table (9): Soluble and DTPA extractable heavy metals in water samples (water table and drain) in $\mu \mathrm{g} \mathrm{L}^{-1}$ and surface layer of soil $\left(\mu \mathrm{g} \mathrm{kg}^{-1}\right)$ for the studied sites.

\begin{tabular}{|c|c|c|c|c|c|c|c|c|c|}
\hline $\begin{array}{l}\text { Site } \\
\text { No. }\end{array}$ & Sample & $\mathrm{Fe}$ & Mn & $\mathrm{Zn}$ & $\mathrm{Cu}$ & $\mathrm{Pb}$ & $\mathrm{Cd}$ & $\mathrm{Ni}$ & $\mathrm{Co}$ \\
\hline \multirow{3}{*}{1} & $S$ & 12016 & 2307 & 1695 & 1101 & 1407 & 76 & 554 & 413 \\
\hline & $\mathrm{G}$ & 1085 & 216 & 160 & 135 & 127 & 13.6 & 85 & 124 \\
\hline & $\mathrm{D}$ & 743 & 155 & 127 & 93 & 87 & 9.7 & 59 & 85 \\
\hline \multirow{3}{*}{2} & $S$ & 6520 & 1452 & 1097 & 697 & 863 & 51 & 398 & 302 \\
\hline & $\mathrm{G}$ & 689 & 139 & 108 & 89 & 78 & 9.2 & 60 & 83 \\
\hline & $\mathrm{D}$ & 587 & 140 & 113 & 85 & 79 & 8.3 & 52 & 72 \\
\hline \multirow{3}{*}{3} & $S$ & 5118 & 1067 & 865 & 549 & 678 & 42 & 310 & 285 \\
\hline & $\mathrm{G}$ & 1165 & 231 & 171 & 145 & 136 & 14.6 & 91 & 133 \\
\hline & $\mathrm{D}$ & 1002 & 209 & 169 & 125 & 117 & 13.1 & 79 & 114 \\
\hline \multirow{3}{*}{4} & $\mathrm{~S}$ & 10132 & 2115 & 1512 & 1078 & 1312 & 72 & 513 & 375 \\
\hline & $\mathrm{G}$ & 987 & 193 & 151 & 129 & 115 & 12.5 & 79 & 118 \\
\hline & $\mathrm{D}$ & 812 & 160 & 128 & 104 & 96 & 10.6 & 62 & 89 \\
\hline \multirow{3}{*}{5} & $\mathrm{~S}$ & 8643 & 995 & 789 & 529 & 623 & 41 & 292 & 267 \\
\hline & $\mathrm{G}$ & 782 & 117 & 89 & 78 & 71 & 7.8 & 48 & 72 \\
\hline & $\mathrm{D}$ & 518 & 104 & 86 & 72 & 65 & 7.2 & 42 & 58 \\
\hline \multirow{3}{*}{6} & $S$ & 7270 & 837 & 675 & 468 & 574 & 37 & 254 & 235 \\
\hline & $\mathrm{G}$ & 369 & 55 & 42 & 37 & 34 & 3.7 & 23 & 34 \\
\hline & $\mathrm{D}$ & 478 & 96 & 79 & 66 & 60 & 6.5 & 39 & 66 \\
\hline \multirow{3}{*}{7} & $S$ & 6021 & 702 & 563 & 359 & 417 & 25 & 207 & 196 \\
\hline & $\mathrm{G}$ & 473 & 96 & 86 & 68 & 61 & 7.1 & 42 & 57 \\
\hline & D & 502 & 101 & 90 & 71 & 64 & 6.7 & 40 & 68 \\
\hline
\end{tabular}

At the same time, pollution by agricultural chemical is particularly dangerous because the enclosed nature the Fayoum depression. Nowadays, the

Fayoum J. Agric. Res. \& Dev., Vol. 21, No.1, January, 2007 
IMPACT OF THE ENVIRONMENTAL CONDITIONS AND.

main sources of heavy metals are attributed to the heavy metal impurities in fertilizers that reach surface water through agricultural run-off, leaching and drainage flows. Also, the great risk of biocides, particularly persistent herbicides residues, and leaching through the relatively coarse texture into the drainage system and lakes. In this concern, in spite of the reuse of drainage water, either directly or mixed with the Nile water, is initiated to alleviate irrigation water shortages, yet such option causes one of the environmental serious problems due to salts and pollutant contents of drainage water, which negatively reflect on the just adjacent soils (Table 9).

Concentrations of major nutritive ( $\mathrm{Fe}, \mathrm{Mn}, \mathrm{Zn}$ and $\mathrm{Cu})$ and non-nutritive $(\mathrm{Pb}, \mathrm{Cd}, \mathrm{Ni}$ and $\mathrm{Co})$ heavy metals were determined in the surface soil layers, underlain groundwater table and the neighbouring drains, beside Lake Qarun. From these data, Table (9), it could be noticed that the concentrations of heavy metals showed a regular distribution pattern in groundwater and both drainage water either in Lake Qarun or drains. At the same time, these water resources (drainage water and groundwater table) at the eastern and middle parts of the studied area, generally, contained relatively high concentrations of soluble heavy metals, then their values tended to decrease westwards away from the effect of both drains, except site 2. This may be attributed to the environmental impact of pollution sources in both parts, which coming from El Batts and El Wadi drains and many anthropogenic activities. These results are in agreement with those obtained by Mohamed and Fishar (2005). In this concern, the clayey soils exhibited higher available contents of all studied heavy metals as compared to both medium and relatively coarse textured ones. This may be due to the former soils had a larger capacity, high CEC, to adsorb these metals from soil solution. The aforementioned two findings are in agreement with those reported by Dohiem et al. (2005) and Reddy and Dunn (1986), respectively.

\section{REFERENCES:}

Abdel Razek, M.A.A. (1998): Land evaluation for sustainable land use planning in the new part of the Fayoum depression, Egypt. M. Sc. Thesis, Inter. Instit. For Aerospace Survey and Earth Sci. (ITC), Enschede, The Netherlands.

Abd El Hamid, N.H. (1973): Micromorphology of soil structure and the main properties of some soil types of Egypt. M. Sc. Thesis, Fac. of Agric., Alexandria Univ., Egypt.

Abd El Motaleb, M.H. (1997): Studies on monitoring of desertification and land degradation processes at El Fayoum depression. M. Sc. Thesis, Fac. of Agric. at El Fayoum, Cairo Univ., Egypt.

Awadallah, A.A. (2004): Characterization of some wetland areas developed under arid and semi-arid climatic conditions of Egypt. Egypt. J of Appl. Sci., 19 (11): 437-460.

Bishai, H.M. and S.Y. Kirollus (1980): The water budget of Lake Qarun and its physio-chemical characteristics. Water Supply and Management, Pergamon Press Ltd, Printed in Great Britain, 4: 93-97.

Black, C.A.; D.D. Evans; L.E. Ensminger; J.L. White and F.E. Clark (1965): Methods of Soil Analysis. Amer. Soc. Agron. Inc., Pub., Madison, Wisc., USA.

Brewer, R. (1964): Fabric and Mineral Analysis of Soils. John Wiley \& Sons, New York.

Dohiem, M.A.; M.Z. Sitohy and N.A Ibrahim (2005): Pesticide residues and heavy metals distribution in Qarun lake, El Fayoum, Egypt: water and fish. Zagazig J. Agric. Res., 32 (5): 1577-1599.

Fayoum J. Agric. Res. \& Dev., Vol. 21, No.1, January, 2007 
El Naggar, M.I.A. (1990): Release of some plant nutrients in the soil under certain conditions. Ph. D. Thesis, Fac. of Agric., Cairo Univ., Egypt.

FAO (1990): Guideline for Soil Profile Description. $3^{\text {rd }}$ Edition, ISRIC Publications, Rome, Italy.

FAO (1992): Waste-water treatment and use in agriculture. Soils Bull. No. 47, Rome, Italy.

Farrag, F.R.M. (2003): Land degradation as affected by irrigation water quality in El Fayoum Governorate. Ph. D. Thesis, Fac. of Agric. at Fayoum, Cairo Univ., Egypt.

Grosheva, E.I.; G.N. Voronskaya and M.V. Pastukhove (2001): Trace elements bioavailability in Lake Baikal. Aquat. Ecosys. Health Manage., 3: 229-234.

Jackson, M.L. (1973): Soil Chemical Analysis. Prentice Hall of India Private Limited, New Delhi. Indian.

Klavins, M.; A. Briede; V. Rodinov; I. Kokorite; E. Parele and I. Klavina (2000): Heavy metals in rivers of Latvia. Sci. Total Environ., 262: 175-184.

Lindsay, W.L. and Norvell, W.A. (1978): Development of DTPA soil test for Zn, $\mathrm{Fe}, \mathrm{Mn}$ and $\mathrm{Cu}$. Soil Sci. Soc. Am. J., 42: 421.

Meshal, A.H. (1973): Water and salt budget of Lake Qarun, Fayoum, Egypt. Ph. D. Thesis, Alexandria Univ., 109pp., Egypt.

Mitsch, W.T. and Gosselink, J.G. (1986): Wetlands. Van Nostrand Reinhold Company, New York, USA.

Mohamed, A.H.H and M.R.A. Fishar (2005): Accumulation of trace metals in some benthic invertebrate and fish species relevant to their concentration in water and sediment of Lake Qarun, Egypt. Egypt. J of Aquatic Res., 31 (1): 289-301.

Page, A.I. ;R.H. Miller and Keeney, D.R. Eds. (1982): Methods of Soil Analysis. Part 2: Chemical and Microbiological Properties. $2^{\frac{n d}{d}}$ Edition, Amer. Soc. of Agron., Madison, Wisconsin, U.S.A.

Piper, C.S. (1950): Soil and Plant Analysis. Int. Sci., Publishers; Inc., New York.

Reddy, M.R. and S.T. Dunn (1986): Heavy metals adsorption by soybean on sewage sludge treated soil. J. Agric. Food Chem., 34: 750-753.

Richards, L.A. (1954): Diagnosis and Improvement of Saline and Alkali Soils. U.S. Dept. of Agric., Hand Book No. 60.

Soil Survey Staff (2003): Key to Soil Taxonomy. $9^{\text {th }}$ Edition, National Resources Conservation Services, USA.

Stoops, G. and Jongerius, A. (1975): Proposal for a micromorphological classification of soil materials. I: A classification of the related distribution of fine and coarse particles. Geoderma, 13: 189-199.

SWRI (1982): Soil map of El Fayoum Governorate. Soils, Water and Environment Research Institute, Agric. Res. Center, Giza, Egypt.

Sys, C. and Verheye, W. (1978): An attempt to the evaluation of physical land characteristics for irrigation to the FAO framework for land evaluation. Int. 1, Trai. Cent. Post Grad. Soil Sci., Ghent, Belgium.

Wright, C.H. (1939): Soil Analysis. Thomas Murby and Co., London. 
IMPACT OF THE ENVIRONMENTAL CONDITIONS AND.

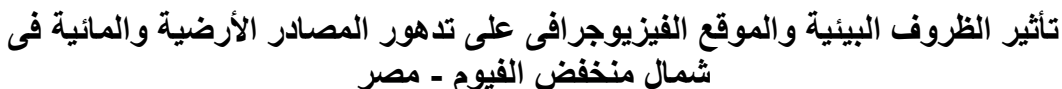

\author{
مصطفى معوض عبد التواب أبو زيد الزيد \\ قسم علوم الأر اضىى - كلية الزر اعة - جامعة القاهرة
}

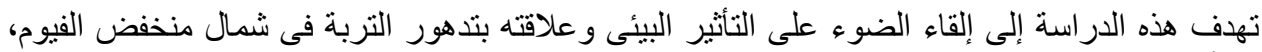

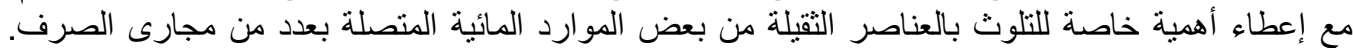

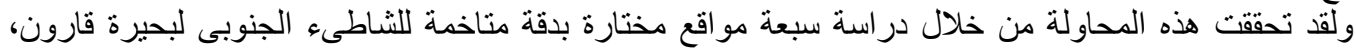

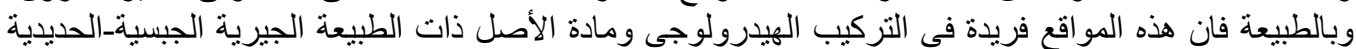

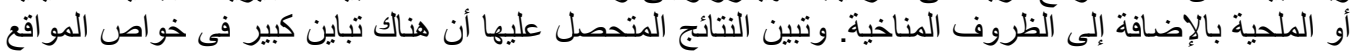

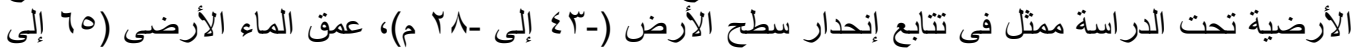

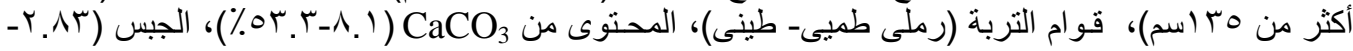

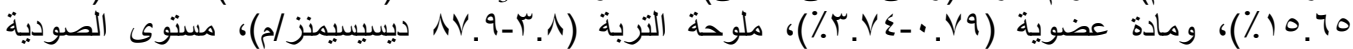

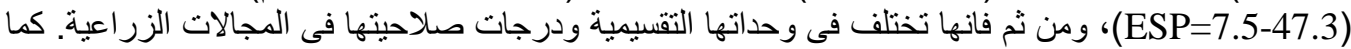

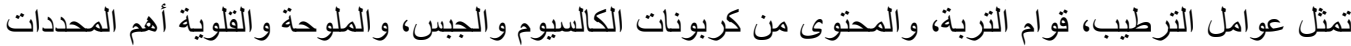

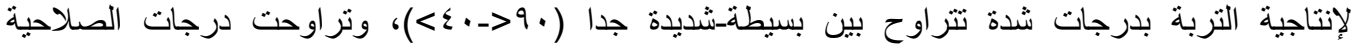

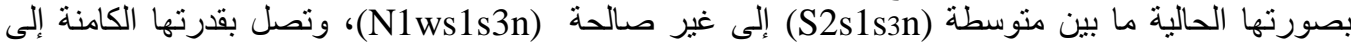

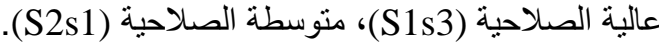

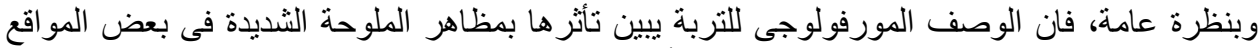

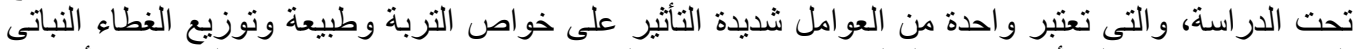

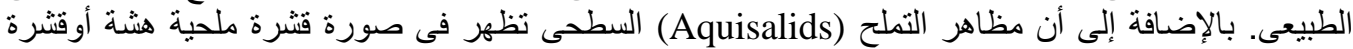

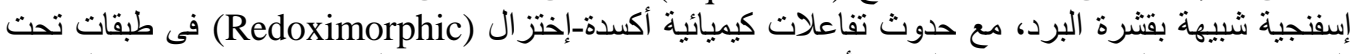

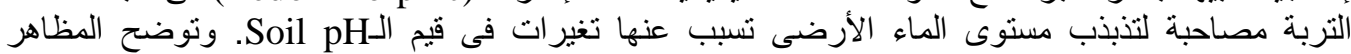

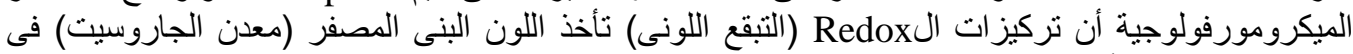

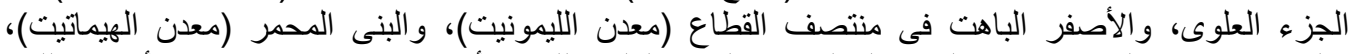

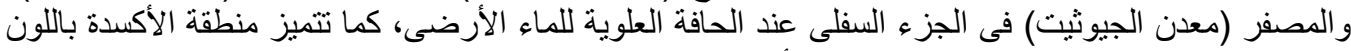

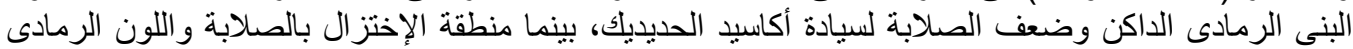

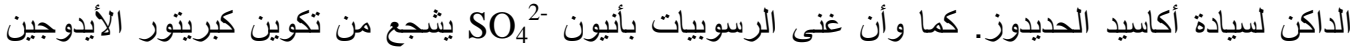

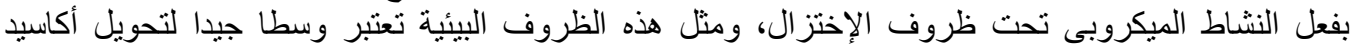

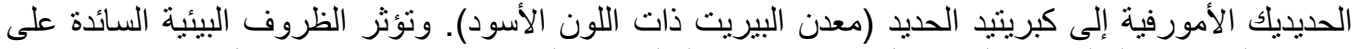

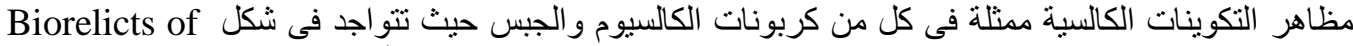
Intercalary clusters of بالنسبة لكربونات الكالسيوم أو shell fragments and orthic lime nodules gypsum crystals

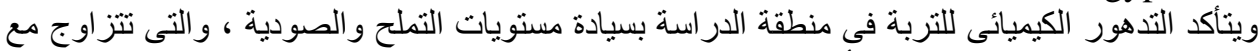

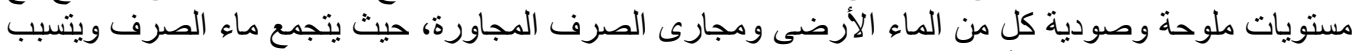

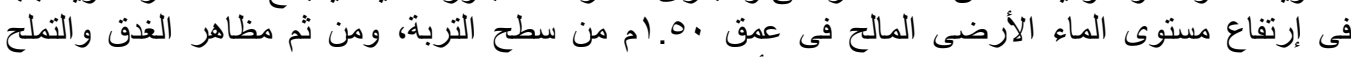

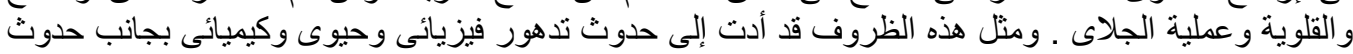

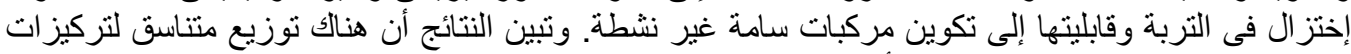

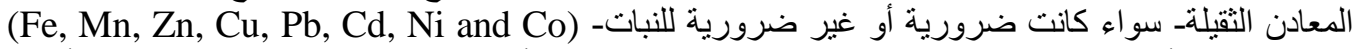

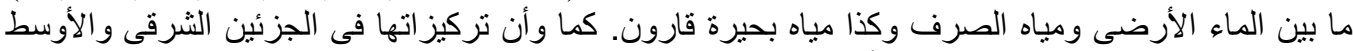

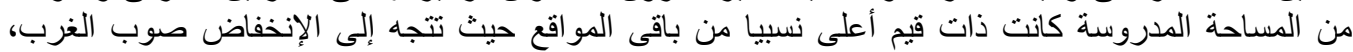

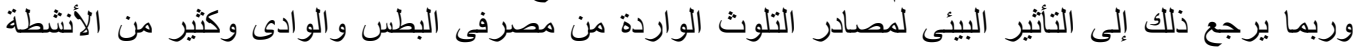

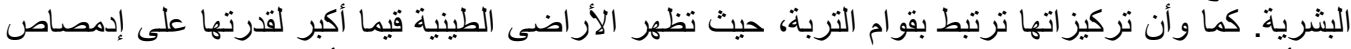

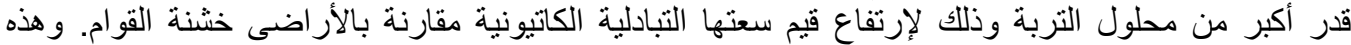

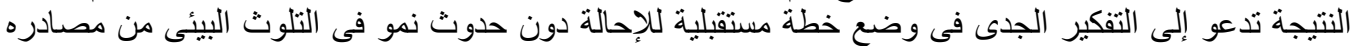

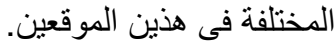

Fayoum J. Agric. Res. \& Dev., Vol. 21, No.1, January, 2007 